\title{
Expression of MDR1, HIF-1 $\alpha$ and MRP1 in sacral chordoma and chordoma cell line CM-319
}

\author{
Zhengang $\mathrm{Ji}^{\dagger}$, Hua Long ${ }^{\dagger}$, Yunsheng Hu${ }^{\dagger}$, Xiuchun Qiu, Xiang Chen, Zhao Li, Degang Fan, Baoan Ma*, Qingyu Fan
}

\begin{abstract}
Background: Chordoma was a typically slow-growing tumor. The therapeutic approach to chordoma had traditionally relied mainly on surgical therapy. And the main reason for therapeutic failure was resistance to chemotherapy and radiotherapy. However the refractory mechanism was not clear. The aim of this study was to investigate the expression of three genes (MDR1, HIF-1 $\alpha$ and MRP1) associated with resistance to chemotherapy and radiotherapy in chordoma and chordoma cell line CM-319.
\end{abstract}

Materials and methods: Using immunohistochemical techniques, the expression of MDR1, HIF-1 $\alpha$ and MRP1 was investigated in 50 chordoma specimen. Using RT-PCR and Western blot, the expression of MDR1, HIF-1 $\alpha$ and MRP1 was investigated in chordoma and chordoma cell line CM-319.

Results: Expression of MDR1, HIF-1 $\alpha$ and MRP1 was observed in 10\%, 80\% and $74 \%$ of all cases, respectively. Expression of MRP1 was correlated with HIF-1 $\alpha$. On the other hand, expression of MDR1 was not correlated with the expression of HIF-1 $\alpha$ or MRP1. The expression of HIF-1 $\alpha$ and MRP1 was observed, but MDR1 was not observed in chordoma and CM-319.

Conclusion: Expression of HIF-1 $\alpha$ and MRP1 was observed in most chordoma specimen and CM-319 cell line; expression of HIF-1 $\alpha$ correlated with MRP1. HIF-1 $\alpha$ and MRP1 may play a role in the multidrug resistance of chordoma to chemotherapy.

\section{Introduction}

Chordoma, a primary malignant tumor of the skeleton, was considered to develop from a remnant of notochordal cells in the midline skeletal axis [1]. The most common sites are the skull base and the sacrococcygeal region. It is typically slow-growing tumor, and initial symptoms are usually related to local progression of the disease with subsequent compression of adjacent structures. The natural course of chordoma is quite grim; most patients do not survive 10 years because of high local recurrence rates $[2,3]$. The therapeutic approach to chordoma has traditionally relied heavily on surgical control. More recently, radiation therapy has been demonstrated to be a valuable modality for local control, particularly with the advent of charged particle radiotherapy. Medical therapy continues to be suboptimal in chordoma which is relatively

\footnotetext{
* Correspondence: gukemba@fmmu.edu.cn; bonetm@fmmu.edu.cn

† Contributed equally Department of Orthopedic Surgery, Orthopedics Oncology Institute of Chinese PLA, Tangdu Hospital, Fourth Military Medical University, Xi'an, Shaanxi Province, 710038, P. R. China
}

C) Biomed Central

(c) $2010 \mathrm{Ji}$ et al; licensee BioMed Central Ltd. This is an Open Access article distributed under the terms of the Creative Commons Attribution License (http://creativecommons.org/licenses/by/2.0), which permits unrestricted use, distribution, and reproduction in any medium, provided the original work is properly cited.

refractory to cytotoxic chemotherapy. The main reason for therapeutic failure in cases of chordoma involves resistance to chemotherapy and radiotherapy. The refractory reason to chemotherapy and radiotherapy may be associated to the over-expression of some multidrug resistance related genes and hypoxia inducible factor- $1 \alpha$. These factors could also provide potential targets for studies on novel therapeutic procedures.

Multidrug resistance is a frequent cause of treatment failure in cancer patients. One mechanism of MDR is over-expression of ATP-binding cassette (ABC) transporter proteins that function as a drug efflux pump. These $A B C$ transporter proteins include P-glycoprotein (P-gp) [4], which is a member of the multidrug resistance-associated protein (MRP) family, the recently identified breast cancer resistance protein (BCRP), and the lung resistance-related vault protein (LRP) identified as the major vault protein (MVP) which are also associated with MDR.

The hypoxia-inducible factor $(H I F)$ is an alpha $(\alpha) /$ beta $(\beta)$ heterodimeric DNA binding complex and 
directs extensive transcriptional responses involving the induction of genes relevant to tumor progression, such as angiogenesis, metabolism, cellular growth, metastasis, and apoptosis. HIF-1 $\alpha$ has emerged as an attractive target for cancer therapy [5,6].

Over-expression of $\mathrm{P}$-gp and MRP is generally believed to be the mechanism responsible for MDR of tumor cells. Hypoxia is a common feature of many malignant tumors. HIF-1 is a key factor in altering the biological characteristics of tumors [7-9]. Many studies indicate that hypoxia helps to improve chemotherapy and radiotherapy resistance of tumors [10-12].

To our knowledge, the mechanism of multidrug resistance to chemotherapy remained largely unknown in chordoma. The present study aimed to investigate the relationship between the expression of HIF-1 $\alpha, M D R 1$ and MRP1 in spinal chordoma as well as their prognostic and predictive value.

\section{Materials and methods Tumors}

A total of 50 primary conventional chordoma specimens between the year 2000 and 2008 (32 males and 18 females) were used for the study. The lesions were obtained from the Department of Pathology (Orthopedics Oncology Institute, Tangdu Hospital, P. R. China). 7 lesions were located in the cervical to lumbar spine and 43 in the sacrococcygeal region, at the age ranging from 31 to 80 years old (the mean age was 58 ). The diagnosis of all cases was confirmed by the co-expression of S-100 protein, Cytokeratin, EMA and Vimentin. Histological sections obtained at biopsy or surgically resected specimens were routinely stained with haematoxylin and eosin for diagnostic purpose. All the specimens were reviewed and diagnosed by two pathological experts. No patient in this study had undergone chemotherapy or radiotherapy before surgery. Nucleus pulposus tissues were resected in 15 patients diagnosed as lubar intervertebral disc protrusion as control. The following clinicopathological and immunohistochemical studies were conducted using sections from $10 \%$ formalin fixed paraffin-embedded tissues, highlighting the representative areas of the tumor. Light microscopic parameters and immunohistochemical analysis using the antibodies were performed in all 50 cases.

For RT-PCR, Western blot, 10 chordoma tissue samples and nucleus pulposus tissues were snap-frozen and stored at $-80^{\circ} \mathrm{C}$ until use. Surgical samples were kept in RPMI 1640 cell culture medium before isolation of chordoma cells (within $2 \mathrm{~h}$ after removal).

\section{Cell culture}

Human chordoma cell line CM-319 was derived from a case of sacral chordoma [13]. The cell line was maintained at $37^{\circ} \mathrm{C}$ under $5 \% \mathrm{CO}_{2}$ in $\mathrm{RPMI} 1640$ medium
(Invitrogene, USA) supplemented with 10\% FCS (Gibco, USA), penicillin (100 units/ml), streptomycin $(100 \mu \mathrm{g} /$ $\mathrm{ml})$ and $1 \%(\mathrm{v} / \mathrm{v})$ L-glutamine.

\section{Immunohistochemical study}

The chordoma tissue samples and CM-319 cells were investigated immunohistochemically for the expression of MDR1 (monoclonal, dilution 1:500; Santa Cruz Biotechnology, USA), MRP1 (monoclonal, dilution 1:500; Santa Cruz Biotechnology, USA), HIF-1 $\alpha$ (monoclonal, dilution 1:500; Santa Cruz Biotechnology, USA). The sections $(4 \mu \mathrm{m})$ were deparaffinized in xylene and then rehydrated through graded alcohols to water. Antigen retrieval for all the studied sections was performed in a one-step procedure with the EDTA (PH 8.0) in a microwave oven by heating for 5 minutes. Endogenous peroxidase activity was blocked using $30 \% \mathrm{H}_{2} \mathrm{O}_{2}$ for $30 \mathrm{~min}$. Nonspecific binding was blocked with $5 \%$ goat serum in phosphate buffer solution (PBS). Sections were incubated with the primary antibodies at the reference working concentration overnight at $4^{\circ} \mathrm{C}$. After washed three times with PBS, secondary antibodies, biotinylated antimouse or rabbit immunoglobulins (dilution 1: 50, Dako, Copenhagen, Denmark) were applied for 30 minutes at room temperature. Detection was performed using the ChemMate $^{\mathrm{Ts}}$ Envision +HRP/DAB kit (Dako, Copenhagen, Denmark). 3'-3'-Diaminobenzidine substrate was used as a chromogen, according to the manufacturer's instructions. Sections were counterstained with hematoxylin. Staining was evaluated independently by two pathologists.

The degree of staining was graded semi-quantitatively according to the percentage of stained cells and their staining intensity. In spinal chordoma, expression of HIF-1 $\alpha$, MDR1 and MRP1 was scored as follows: 0, none; $1,<10 \% ; 2,10-50 \%$; and $3,>50 \%$ [14-18].

\section{RNA isolation and reverse transcription-polymerase chain reaction ( $R T-P C R$ )}

Total RNA was isolated either from frozen tissue or CM-319 cells with Trizol reagent (Invitrogen, USA). cDNA was prepared according to standard methods: RNA was reverse-transcribed with oligo(dT) primer using $1 \mu \mathrm{g}$ total RNA in a total volume of $20 \mu \mathrm{l}$ containing transcription buffer, RNase Inhibitor, Prime Script ${ }^{\text {TM }}$ RTase. For PCR, 30 cycles of denaturation $\left(94^{\circ} \mathrm{C}\right.$ for $45 \mathrm{~s})$, annealing $\left(60^{\circ} \mathrm{C}\right.$ for $\left.45 \mathrm{~s}\right)$, and elongation $\left(72^{\circ} \mathrm{C}\right.$ for $1 \mathrm{~min})$ was performed using the following primer pairs for HIF-1 $\alpha$ [19]: forward: 5'-TGGACTCTGATCATCTGACC-3', reverse: 5'-CTCAAGTTGCTGGTCATCAG3 ', which yielded a 434-bp product. 30 cycles of denaturation $\left(95^{\circ} \mathrm{C}\right.$ for $\left.1 \mathrm{~min}\right)$, annealing $\left(55^{\circ} \mathrm{C}\right.$ for $\left.60 \mathrm{~s}\right)$, and elongation $\left(72^{\circ} \mathrm{C}\right.$ for $\left.1 \mathrm{~min}\right)$ were performed using the following primer pairs for MDR1 [20]: forward: 
5'-GAATCTGGAGGAAGACATGACC-3', reverse:5'TCCAATTTTGTCACCAATTCC-3', which yielded a 259-bp product. 35 cycles of denaturation $\left(95^{\circ} \mathrm{C}\right.$ for $\left.30 \mathrm{~s}\right)$, annealing $\left(50^{\circ} \mathrm{C}\right.$ for $\left.1 \mathrm{~min}\right)$, and elongation $\left(72^{\circ} \mathrm{C}\right.$ for $1 \mathrm{~min}$ ) were performed using the following primer pairs for MRP1 [21]: forward: 5'-TCAGCCCTTCCTGACAA GCT-3', reverse: 5'-TCTCTGCTGCAGGAGGTCCG-3', which yielded a 318-bp product. The GAPDH [22] control PCR was performed using the following primer pairs: forward: 5'-ACCACCATGGAGAAGGCTGG-3', reverse: 5'-CTCAGTGTAGCCCAGGATGC-3', which yielded a 527-bp product. For negative controls, the PCR reaction was performed without prior reverse transcription. Amplified cDNA was visualized by ethidium bromide staining on 1.5\% agarose gels on a Bio-Rad gel scanner (Bio-Rad, USA).

\section{Western Blot}

The chordoma cell line CM-319 and frozen nucleus pulposus tissues were harvested and lysed with a cold RIPA protein lysis buffer for 30 minutes on ice. The lysates were transferred to Eppendorf tubes and clarified by centrifugation at $12,000 \mathrm{~g}$ for 10 minutes at $4^{\circ} \mathrm{C}$. The supernatant was kept in $-80^{\circ} \mathrm{C}$ for future use. The BCA method was performed to determine the protein concentration in the supernatant. Samples (30 $\mu \mathrm{g}$ of total protein each) were boiled at $95^{\circ} \mathrm{C}$ for five minutes and loaded onto SDSPAGE (5\% stacking gel and 8\% separating gel), followed with a separation at 80 volts for about two hours and subsequent transferred onto a nitrocellulose membrane. The membrane was blocked in 5\% defatted milk for 1 hour at room temperature, and was then incubated in the primary antibodies diluted in 5\% defatted milk/TBST overnight at $4^{\circ} \mathrm{C}$ (MDR1 1:200, mouse anti-human, Santa Cruz; MRP1, 1:200, rabbit anti-human, Santa Cruz; HIF-1 $\alpha, 1: 200$, rabbit anti-human, Santa Cruz). The membrane was washed three times with TBST and incubated with the second antibodies for an hour at room temperature, then washed three times with TBST again. The enhanced chemiluminescene (ECL) system (Piece) was used for detection of MDR1, HIF- $1 \alpha$ and MRP1. Protein bands were visualized and quantified using Quantity-One software (Bio-Rad USA). The MDR1, HIF- $1 \alpha$ and MRP1 bands were visualized at an apparent molecular weight of 170, 120 and $190 \mathrm{kDa}$, respectively.

\section{Statistical analysis}

Relationship between the expression of HIF-1 $\alpha$, MDR1 and MRP1 were defined using Kruskal-Wallis test ( $x^{2}$ or Fisher's exact test). Correlations among three markers were described using the Spearman rank correlation test. Correlations between the expression of three markers and patient age, MIB-1 labelling index were estimated using the Mann-Whitney U test. All calculations and analyses were performed with SPSS 12.0 for Windows. Significance was considered to be $P<0.05$.

\section{Results}

\section{Expression of HIF-1 $\alpha$, MRP1 and MDR1 in human chordomas}

Different pattern of immunoreactivity was found as membranous or cytoplasmic staining for MDR1 and MRP1, while cytoplasmic, part of nuclear positive for HIF-1 $\alpha$. MDR1 positive staining was found in five (10\%) of the 50 lesions which scored 1 (Figure 1E, F), and scored 0 in the remaining lesions. Thirteen of the 50 lesions were assigned to MRP1 score 0 ; three of the lesions scored 1; eighteen lesions scored 2; and sixteen lesions scored 3. Ten of the 50 lesions were assigned to HIF- $1 \alpha$ score 0 ; four of the lesions scored 1; fourteen lesions scored 2; and twenty-two lesions scored 3. As a consequence, 37 (74\%) lesions expressed MRP1 with score $\geq 1 ; 16$ (32\%) lesions showed strong expression with score 3 (Figure 1C, D). 40 (80\%) lesions expressed HIF- $1 \alpha$ with score $\geq 1 ; 22$ (44\%) lesions showed strong expression with score 3 (Figure 1A, B). Expression of HIF-1 $\alpha$ in chordoma was much higher than that in nucleus pulposus; expressiong of MRP1 in chordoma was also much higher than that in nucleus pulposus; but expression of MDR1 in chordoma was not different from that in nucleus pulposus. (Table 1)

\section{Correlation of antibody expression in chordomas tumors}

Using Kruskal-Wallis test, we examined the relationship among MDR1, MRP1 and HIF-1 $\alpha$. For spinal chordoma tumors, whether primary or recurrent, we found that the overall immunoreactivity score of MRP1 or HIF- $1 \alpha$ was higher in cases showing expression of MDR1. There was no correlation between the expression of MDR1, MRP1, HIF- $1 \alpha$ expression and patient age, gender. There was no relationship between MDR1 expression and either MRP1 or HIF-1 $\alpha$ expression. There was a significant correlation between HIF- $1 \alpha$ expression and MRP1 expression level. Chordomas that had high MRP1 expression were also likely to have high HIF-1 $\alpha$ expression. (Table 2)

\section{RT-PCR analysis of HIF-1 $\alpha, M D R 1$ and MRP1 in chordoma cells}

Anaylsis of $H I F-1 \alpha, M D R 1$ and MRP1 mRNA was conducted in CM-319 and chordoma by RT-PCR analysis using three pairs of primers designed for the human $H I F-1 \alpha, M D R 1$ and MRP1 sequences. A 437-, 257-, 328-bp fragment should be obtained for HIF-1 $\alpha, M D R 1$ and $M R P 1$ as expected, respectively. Amplification of 547-bp fragment of GAPDH was used as an internal control for the integrity of the isolated mRNA. A positive $H I F-1 \alpha$ and $M R P 1$, but a negative $M D R 1$ was observed in CM-319 cells (Figure 2). 


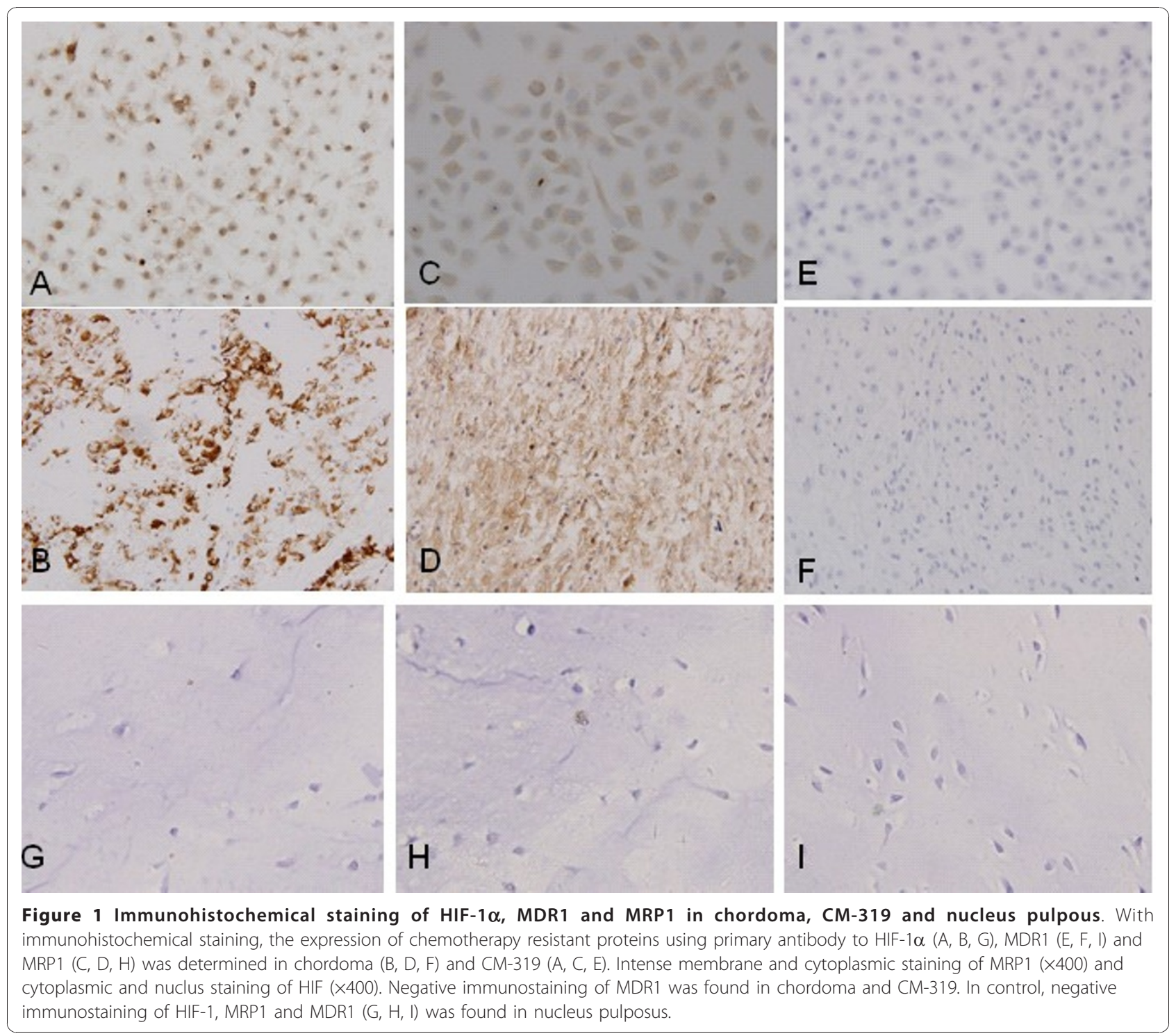

Table 1 Expression of HIF-1 $\alpha$, MRP1 and MDR1 in chordoma tissue and nucleus pulposus tissue

\begin{tabular}{lccccc}
\hline & positive & negative & positive rate & $\chi^{2}$ & $P$ \\
\hline HIF-1 $\alpha$ (n) & & & & & \\
chordoma & 40 & 10 & $80 \%$ & 18.55 & $<0.005$ \\
nucleus pulposus & 3 & 12 & $20 \%$ & & \\
MRP1 (n) & & & & & \\
chordoma & 37 & 13 & $74 \%$ & 11.10 & $<0.005$ \\
nucleus pulposus & 4 & 11 & $26.7 \%$ & & \\
MDR1 (n) & & & & & \\
chordoma & 5 & 45 & $10 \%$ & 0.343 & $>0.5$ \\
nucleus pulposus & 3 & 12 & $20 \%$ & & \\
\hline
\end{tabular}

Western blot of HIF-1 $\alpha$, MDR1 and MRP1 in chordoma cells Expression of HIF-1 $\alpha$, MDR1 and MRP1 in CM-319 cells was detected by immunoblotting. The results showed no positive band with a molecular weight of $170 \mathrm{KD}$ in $\mathrm{CM}-319$, which indicated the negative

Table 2 Correlation with the expression of HIF-1 $\alpha$, MRP1

\begin{tabular}{lccccc}
\hline & & HIF-1 $\boldsymbol{\alpha}(\mathbf{n})$ & MRP1(n) & $\boldsymbol{r}$ & $\boldsymbol{P}$ \\
\hline negative & 0 & 10 & 13 & 0.8 & $<0.01$ \\
positive & 1 & 4 & 3 & & \\
& 2 & 14 & 18 & & \\
& 3 & 22 & 16 & & \\
\hline
\end{tabular}




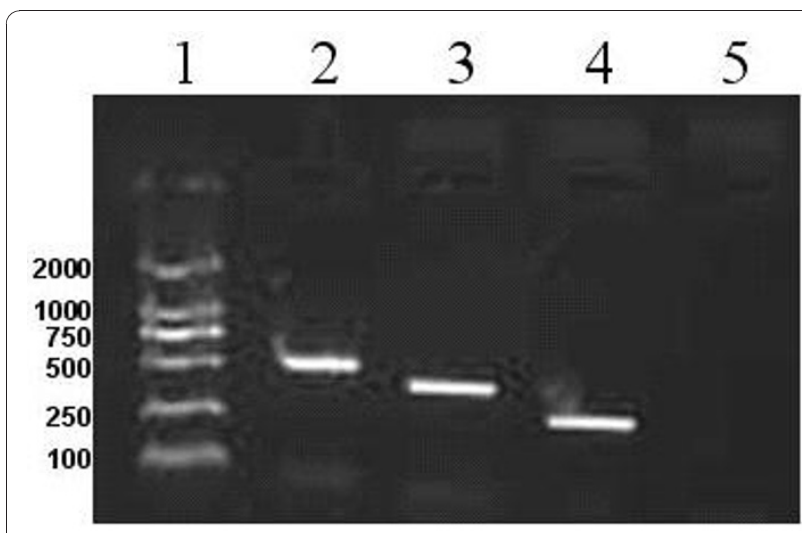

Figure 2 RT-PCR analysis of MDR1, HIF-1 $\alpha$ and MRP1 messenger RNA (mRNA) expression in CM-319 cell line and chordoma. A significant HIF- $1 \alpha$ and MRP1 mRNA expression was observed, but a negative MDR1 expression was observed in CM-319 cell line and chordomas. But negative expression of MDR1, HIF-1 $\alpha$ and MRP1 messenger RNA (mRNA) in nucleus pulposus. Amplification of a 547-bp fragment of GAPDH was used as an internal control for the integrity of the isolated mRNA. Lane 1: Marker; Lane 2: GAPDH; Lane 3: HIF-1 $\alpha$; Lane 4: MRP1; Lane 5: MDR1.

expression of MDR1 in CM-319, but strong positive expression of HIF-1 $\alpha$ and MRP1 at $120 \mathrm{KD}$ and $190 \mathrm{KD}$ in the membrane in CM-319 cells. These results were reproduced in repeat experiments of independent membrane preparations and a representative blot is shown in Figure 3.

\section{Discussion}

Chordoma was not reported to be sensitive to chemotherapy, similar to many other low-grade malignancies. Accordingly, chemotherapy response had been reported in patients with high-grade dedifferentiated chordoma, which represented $<5 \%$ of all chordoma [23].

The modern multi-modality therapeutic approach to chordoma, combining surgery with radiotherapy and chemotherapy, resulted in high cure rates even in advanced stage disease, with the pivotal role attributed to chemotherapy. However, there were still cases which exhibited either primary or secondary drug resistance with dismal outcomes [24]. Drug resistance was a major obstacle for clinical management and was attributable to several processes taking place in many kinds of tumor cells. One of these processes was the decreased accumulation of drugs within cancer cells due to drug efflux mediated by $\mathrm{ABC}$ multidrug transporters. Over-expression of these transporters was an adverse prognostic factor in a number of cancers. The significance of the expression of these $A B C$ proteins in chordoma had not yet been reported.

Cellular adaptation to hypoxia was a critical step in tumor progression [25]. Hypoxia occurred during several

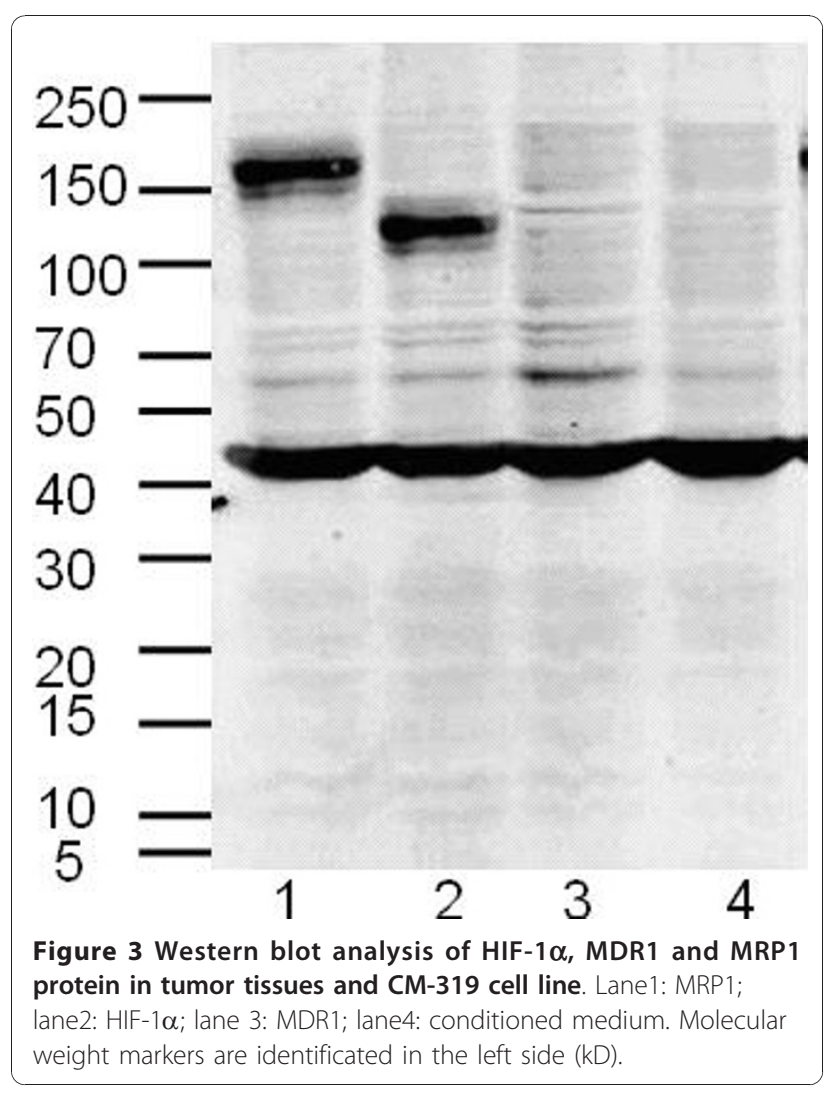

pathophysiological processes including tumorigenesis, which was a reduction in the normal level of tissue oxygen tension. Hypoxic cancer cells might undergo a series of genetic and metabolic changes that allowed them not only to survive and proliferate but also to become more resistance to conventional therapies including ionizing radiation and chemical agents. These hypoxic adaptations made the tumors more difficult to treat and confer increased resistance to death from chemotherapy and radiotherapy. In response to hypoxia, cells altered the expression of genes that encoded protein products involved in increasing oxygen delivery and activated alternate metabolic pathways that did not require oxygen. This hypoxic response was chiefly regulated by $H I F-1 \alpha$.

Magnon's [10] findings supported a crucial role for angiogenesis inhibitors in shifting the fate of radiationinduced HIF-1 $\alpha$ activity from hypoxia-induced tumor radioresistance to hypoxia-induced tumor apoptosis. Sullivan [12] determined the effects of hypoxia on multiple forms of drug-induced death in human MDA-MB-231 breast carcinoma cells. These results supported a requirement for $H I F-1$ in the adaptations leading to drug resistance and revealed that decreased drug-induced senescence was also an important contributor to the development of hypoxia-induced resistance. Nardinocchi [26] reported that the mechanistic explanation of 
hypoxia-induced chemoresistance involved upregulation of $H I F-1$ pathway and inhibition of the $p 53$ pathway that were partly interconnected by the hypoxia-induced HIPK2 deregulation. They showed for the first time that hypoxiainduced HIPK2 deregulation was counteracted by zinc that restored HIPK2 suppression of HIF-1 pathway and reactivated $p 53$ apoptotic response to drug, underscoring the potential use of zinc supplementation in combination with chemotherapy to address hypoxia and improve tumor treatment. It has been recently reported $[27,28]$ that the transcription of MDR1 gene was controlled by hypoxia; HIF-1 binding to a putative binding site of human MDR1 promoter was critical for the transcription. Song [29] demonstrated that hypoxia-induced chemoresistance to cisplatin and doxorubicin in NSCLC cells was through the HIF pathway. MDR1 regulation may not be involved in hypoxia-induced chemoresistance. Combining delivery of HIF-1 $\alpha$ RNAi lentiviral vector with cisplatinrelated chemotherapy regimens could enable us to develop more effective strategy for NSCLC therapy. Ding [15] suggested that hypoxia induce the expression of HIF- $1 \alpha$ and P-gp in colon carcinoma and HIF-1 $\alpha$ expression may be associated with P-gp and interactively involved in the occurrence of tumor multidrug resistance.

In this study, we described the expression of these three different proteins associated with multidrug resistance and radiotherapy in chordoma. All the tested markers exhibited some changes in their expression pattern in chordoma compared with normal nucleus pulpous. The most prominent reduction in expression was observed for MDR1 which was very weakly expressed or unexpressed in more than $50 \%$ of the chordoma samples studied. To our knowledge, this was the first study on genes associated with resistance to chemotherapy and radiotherapy in spinal chordoma. The current results showed that MRP1was expressed in the membranous and intracellular regions; $H I F-1 \alpha$ was expressed in the cell cytoplasmic and nuclear regions, whereas $M D R 1$ was not expressed in the chordoma tissues or CM-319 cell.

$\mathrm{ABC}$ multidrug transporters also played an important role in the establishment of important biological barriers such as the placenta, the blood-brain barrier, and the blood-testes barrier. Although the over-expression of these transporters was a common phenomenon in chemoresistant tumor cells, we found that MRP1 and HIF-1 $\alpha$ expression was upregulated in most chordoma tissues in comparison to normal tissues. It had been proposed that upregulation of $\mathrm{ABC}$ multidrug transporters in cancers may play a role in tumorigenesis by enhancing exposure of tissues to carcinogenic xenobiotics. Interestingly, the expression of MDR1 was not inversely expressed in the chordoma tissues.

New data on HIF-1 signaling and the potential for targeted therapies, including combinations of hormonal therapies for cancer and selective investigational HIF-1 $\alpha$ inhibiting small molecules would be discussed. Another mechanism by which hypoxia could increase chemoresistance was to enhance the expression of MDR1 gene via a HIF-1-dependent regulation [30,31].

\section{Abbreviations}

HIF- $1 \alpha$ : hypoxia-inducible factor alpha $(\alpha)$ heterodimeric; MDR1/P-GP: multidrug resistance gene/P-glycoprotein; MRP1: multidrug resistanceassociated protein 1

\section{Acknowledgements}

This work was supported by grants from the National Natural Science Foundation of P. R. China (No. 30873027, No.30973409 and No.30330610) and major issues Foundation of health department in Shaaxi province (No. 2010K13-02-05). The authors thank Dr Lianjia Yang and Ms Yanhua Wen (Orthopadepics Department, Tangdu Hospital, the Fourth Military Medical University, Xi'an, P. R. China) for their pathological diagnosis. We thank Ms Yunyan Liu and Ms Qiong Ma (Orthopadepics Department, Tangdu Hospital, the Fourth Military Medical University, Xi'an, P. R. China) for their skillful technical assistance. We are also grateful to Dr Tongtao Yang, Dr Dianzhong Zhang, Dr Yong Zhou and Dr Minghua Zhang (Orthopadepics Department, Tangdu Hospital, the Fourth Military Medical University, Xi'an, P. R. China) for their helpful discussion.

\section{Authors' contributions}

ZJ and HL conceived of the study, and participated in its design and coordination and helped to draft the manuscript. YH, XQ and XC carried out the molecular genetic studies. ZL and DF participated in its design and coordination. BM and QF participated in the conception and the design of the analysis. All authors read and approved the final manuscript.

\section{Competing interests}

The authors declare that they have no competing interests.

Received: 6 October 2010 Accepted: 8 December 2010 Published: 8 December 2010

\section{References}

1. Chugh R, Tawbi H, Lucas DR, Biermann JS, Schuetze SM, Baker LH: Chordoma: the nonsarcoma primary bone tumor. Oncologist 2007, 12:1344-1350.

2. Azzarelli A, Quagliuolo V, Cerasoli S, Zucali R, Bignami P, Mazzaferro V, Dossena G, Gennari L: Chordoma: natural history and treatment results in 33 cases. J Surg Oncol 1988, 37:185-191.

3. Baratti D, Gronchi A, Pennacchioli E, Lozza L, Colecchia M, Fiore M, Santinami M: Chordoma: natural history and results in 28 patients treated at a single institution. Ann Surg Oncol 2003, 10:291-296.

4. Cordon-Cardo C, O'brien JP, Casals D, Rittman-Grauer L, Biedler JL, Melamed MR, Bertino JR: Multidrug-resistance gene (P-glycoprotein) is expressed by endothelial cells at blood-brain barrier sites. Proc Natl Acad Sci USA 1989, 86:695-698.

5. Kunz M, Ibrahim SM: Molecular responses to hypoxia in tumor cells. Mol Cancer 2003, 2:23.

6. Harris AL: Hypoxia-a key regulatory factor in tumour growth. Nat Rev Cancer 2002, 2:38-47.

7. Mabjeesh NJ, Amir S: Hypoxia-inducible factor (HIF) in human tumorigenesis. Histol Histopathol 2007, 22:559-572.

8. Jensen RL, Ragel BT, Whang K, Gillespie D: Inhibition of hypoxia inducible factor-1alpha (HIF-1alpha) decreases vascular endothelial growth factor (VEGF) secretion and tumor growth in malignant gliomas. J Neurooncol 2006, 78:233-247.

9. Nagle DG, Zhou YD: Natural product-based inhibitors of hypoxiainducible factor-1 (HIF-1). Curr Drug Targets 2006, 7:355-369.

10. Magnon C, Opolon P, Ricard M, Connault E, Ardouin P, Galaup A, Métivier D, Bidart JM, Germain S, Perricaudet M, Schlumberger M: Radiation and inhibition of angiogenesis by canstatin synergize to induce HIF-1alphamediated tumor apoptotic switch. J Clin Inves 2007, 117:1844-1855. 
11. Schnitzer SE, Schmid T, Zhou J, Brune B: Hypoxia and HIF-1alpha protect A549 cells from drug-induced apoptosis. Cell Death Differ 2006, 13:1611-1613.

12. Sullivan R, Paré GC, Frederiksen LJ, Semenza GL, Graham CH: Hypoxiainduced resistance to anticancer drugs is associated with decreased senescence and requires hypoxia-inducible factor- 1 activity. Mol Cancer Ther 2008, 7:1961-1973.

13. Zhang DZ, Ma BA, Fan QY, Chang H, Wen YH: Establishment and characteristics of a human chordoma cell line. Zhonghua Zhong Liu Za Zhi 2003, 25:234-237.

14. Naka T, Boltze C, Samii A, Samii M, Herold C, Ostertag H, Iwamoto Y, Oda Y, Tsuneyoshi M, Kuester D, Roessner A: Expression of c-MET, low-molecularweight cytokeratin, matrix metalloproteinases-1 and -2 in spinal chordoma. Histopathology 2009, 54:607-613.

15. Zhenyu Ding, Li Yang, Xiaodong Xie, Fangwei Xie, Feng Pan, Jianjun Li, Jianming He, Houjie Liang: Expression and significance of hypoxiainducible factor-1 alpha and MDR1/P-glycoprotein in human colon carcinoma tissue and cells. J Cancer Res Clin Oncol 2010, 136:1697-1707.

16. Chen WT, Huang CJ, Wu MT, Yang SF, Su YC, Chai CY: Hypoxia-inducible factor-1alpha is associated with risk of aggressive behavior and tumor angiogenesis in gastrointestinal stromal tumor. Jpn J Clin Onco 2005, 35:207-213.

17. Hodorová I, Rybárová S, Solár P, Vecanová J, Mihalik J, Bohus P, Mellová Y, Kluchová D: Multidrug resistance proteins in renal cell carcinoma. Folia Biol (Praha) 2008, 54:187-192.

18. Mignogna C, Staibano S, Altieri V, De Rosa G, Pannone G, Santoro A, Zamparese R, D'Armiento M, Rocchetti R, Mezza E, Nasti M, Strazzullo V, Montanaro V, Mascolo M, Bufo P: Prognostic significance of multidrugresistance protein (MDR-1) in renal clear cell carcinomas: a five year follow-up analysis. BMC Cancer 2006, 6:293.

19. Fukushima K, Murata M, Hachisuga M, Tsukimori K, Seki H, Takeda S, Asanoma K, Wake N: Hypoxia inducible factor 1 alpha regulates matrigelinduced endovascular differentiation under normoxia in a human extravillous trophoblast cell line. Placenta 2008, 29:324-331.

20. Enokida H, Shiina H, Igawa M, Ogishima T, Kawakami T, Bassett WW Anast JW, Li LC, Urakami S, Terashima M, Verma M, Kawahara M, Nakagawa M, Kane CJ, Carroll PR, Dahiya R: CpG hypermethylation of MDR1 gene contributes to the pathogenesis and progression of human prostate cancer. Cancer Res 2004, 64:5956-5962.

21. Larbcharoensub N, Leopairat J, Sirachainan E, Narkwong L, Bhongmakapat T, Rasmeepaisarn K, Janvilisri T: Association between multidrug resistance-associated protein 1 and poor prognosis in patients with nasopharyngeal carcinoma treated with radiotherapy and concurrent chemotherapy. Hum Pathol 2008, 39:837-845.

22. Neaud V, Faouzi S, Guirouilh J, Le Bail B, Balabaud C, Bioulac-Sage P, Rosenbaum J: Human hepatic myofibroblasts increase invasiveness of hepatocellular carcinoma cells: evidence for a role of hepatocyte growth factor. Hepatology 1997, 26:1458-1466.

23. Fleming GF, Heimann PS, Stephens JK, Simon MA, Ferguson MK, Benjamin RS, Samuels BL: Dedifferentiated chordoma. Response to aggressive chemotherapy in two cases. Cancer 1993, 72:714-718.

24. Rhomberg W, Böhler FK, Novak H, Dertinger S, Breitfellner G: A small prospective study of chordomas treated with radiotherapy and razoxane. Strahlenther Onkol 2003, 179:249-253.

25. Dang CV, Semenza GL: Oncogenic alteration of metabolism. Trends Biochem Sci 1999, 24:68-72.

26. Nardinocchi L, Puca R, Sacchi A, Rechavi G, Givol D, D'Orazi G: Targeting hypoxia in cancer cells by restoring homeodomain interacting proteinkinase 2 and p53 activity and suppressing HIF-1alpha. PLoS One 2009, 4 e6819.

27. Comerford KM, Cummins EP, Taylor CT: c-Jun NH2-terminal kinase activation contributes to hypoxia-inducible factor 1alpha dependent $\mathrm{P}$ glycoprotein expression in hypoxia. Cancer Res 2004, 64:9057-9061.

28. Zhu H, Chen XP, Luo SF, Guan J, Zhang WG, Zhang BX: Involvement of hypoxia-inducible factor-1-alpha in multidrug resistance induced by hypoxia in HepG2 cells. J Exp Clin Cancer Res 2005, 24:565-574.

29. Song X, Liu X, Chi W, Liu Y, Wei L, Wang X, Yu J: Hypoxia-induced resistance to cisplatin and doxorubicin in non-small cell lung cancer is inhibited by silencing of HIF-1alpha gene. Cancer Chemother Pharmacol 2006, 58:776-784.
30. Comerford KM, Wallace TJ, Karhausen J, Louis NA, Montalto MC, Colgan SP: Hypoxia-inducible factor-1-dependent regulation of the multidrug resistance (MDR1) gene. Cancer Res 2002, 62:3387-3394.

31. Thottassery JV, Zambetti GP, Arimori K, Schuetz EG, Schuetz JD: p53dependent regulation of MDR1 gene expression causes selective resistance to chemotherapeutic agents. Proc Natl Acad Sci USA 1997, 94:11037-11042.

doi:10.1186/1756-9966-29-158

Cite this article as: $\mathrm{Ji}$ et al.: Expression of MDR1, HIF-1 $\alpha$ and MRP1 in sacral chordoma and chordoma cell line CM-319. Journal of Experimental \& Clinical Cancer Research 2010 29:158.

\section{Submit your next manuscript to BioMed Central and take full advantage of:}

- Convenient online submission

- Thorough peer review

- No space constraints or color figure charges

- Immediate publication on acceptance

- Inclusion in PubMed, CAS, Scopus and Google Scholar

- Research which is freely available for redistribution

Submit your manuscript at www.biomedcentral.com/submit
Biomed Central 